\title{
Impact of Fruit Zone Leaf Removal on Fruit Quality and Yield of King's Ruby Grapes (Vitis vinifera L.)
}

\author{
Allah Bakhsh ${ }^{1}$, Attiq Akhtar ${ }^{*}$, Fiaz Hussain ${ }^{1}$ and Shabbir Ahmed ${ }^{2}$
}

${ }^{1}$ Horticultural Research Station, Nowshera (Soon Valley), Pakistan; ${ }^{2}$ Horticultural Research Institute, AARI, Faisalabad, Pakistan.

\begin{abstract}
Bunch rot is a fungal disease and causes significant yield loses to grapes yield every year. Fruit Zone Leaf Removal (FZLR) is a canopy management technique that provides a cost-effective and high-quality grape yield. In order to boost grape quality and minimize disease incidence in the King's Ruby variety, FZLR was used for two seasons in a row. Total leaf removal was used before bloom, during full bloom, and four weeks after bloom, and was compared to an untreated control (non-defoliated). In all leaf removal treatments, titratable acidity and bunch rot incidence decreased significantly, while total soluble solids, total phenolic content, total sugars, and reducing sugars increased significantly when compared to regulation. In comparison to the other treatments, the growth of lateral shoots was significantly higher in the control.At bloom and four weeks after bloom, FZLR increased the fruit's quality attributes. The proper penetration of light and air in the plants, as a result of leaf removal, decreases the occurrence and severity of bunch rot to less than 5\%. This method is extremely useful for maintaining grape quality and quantity without the use of chemicals to combat disease. As a result, this strategy is both environmentally and health-friendly. In Pakistan, we consider using leaf removal therapy to treat grape bunch rot disease because it is the least expensive.

Received | December 06, 2019; Accepted | March 28, 2021; Published | June 21, 2021

*Correspondence | Attiq Akhtar, Horticultural Research Station, Nowshera (Soon Valley), Pakistan; Email: attiqakhtar@gmail.com

Citation | Bakhsh, A., A. Akhtar, F. Hussain and S. Ahmed.2021. Impact of fruit zone leaf removal on fruit quality and yield of king's ruby grapes (Vitis vinifera L.). Sarhad Journal of Agriculture, 37(3): 774-780.

DOI | https://dx.doi.org/10.17582/journal.sja/2021/37.3.774.780

Keywords | Canopy management, Grapes, Pruning, Bunch rot disease, Environment friendly therapy, Quality assurance
\end{abstract}

\section{Introduction}

G rapes (Vitis vinifera L.) are the world's most common and widely consumed fruit crop. They're high in antioxidants (Zhou and Raffoul, 2012), that are known to lower the risk of heart disease and type 1 diabetes (Mijowska et al., 2016). Furthermore, the fruit's phenolic compounds have anti-cancer, antiaging, and anti-inflammatory effects (Xia et al., 2010; Toaldo et al., 2016).

Quality attributes i.e., color, size and shape of the berries and cluster are important parameters of grapes. Compactness of the clusters is also of immense consideration for table grapes (Ozer et al., 2012). Defoliation and canopy maintenance have been shown to increase grape quality attributes (Palliotti et al., 2013). To achieve high yields and good quality grapes, a variety of techniques are used around the world. The removal of leaves from both sides of the branch was done manually. Development will be affected by timing and intensity, as well as combinations of shoot thinning and defoliation (Kemp et al., 2010). Leaf removal in the fruit zone is used to increase fruit quality, reduce disease incidence, and improve management strategies (Austin et al., 2011; English et al., 1989; Komm and Moyer, 2015; Vicente and Yuste, 2015; Radwan and Masood, 
2017). It is usually performed in grapes between the fruit-set and veraison stages. The benefits are derived from the impact on the source sink relationships and hormone balance, as well as indirectly from improved light penetration and air circulation within the canopy (Gerasopoulos and Drogoudi, 2005) and regulation of cluster temperature, which results in improved berry quality and colour (Reynolds et al., 1996).

Climate conditions, among other factors, are considered to have a significant impact on the nutritional quality and chemical composition of grapes (Coombe, 1987).Temperature and rainfall are the two most important climatic factors that influence berry maturity and ripening, as well as the physical and chemical composition of fragrance, colour, scale, and anthocyanin accumulation (Jackson and Lombard, 1993; Kashif et al., 2018).Cultivar, topography, and the prevailing environmental conditions affect the timing of grape maturity, ripening, and harvesting (Intrigliolo et al., 2014). The aim of the research was to see how the intensity and timing of leaf removal influenced the qualitative and quantitative characteristics of King's Ruby grapes in the existing seasonal conditions.

\section{Materials and Methods}

The research was carried out at the Horticultural Research Station (32 33'52.7”N, 7208'27.8”E), Nowshera, Soon Valley, District Khushab, PunjabPakistan during 2017 and 2018 as shown in (Table 1). King's Ruby is a common grape cultivar with red skinned grapes that grow in semi-compact bunches and the grapes ripen before the onset of the rainy season in Soon Valley, District Khushab, PunjabPakistan. The famous grape variety "King's Ruby" was tested because it matures early before the rainy season begins. Leaf removal consisted of removing all leaves along with lateral shoots of the fruit zone on both sides of the cluster before full bloom, at opening of all flowers (full bloom), four weeks after bloom while no leaves were removed in control. There were four replications for each treatment, which consisted of four plants. All leaf removal was maintained until harvest. The fruit was harvested at physiological maturity stage (TSS 18 and above). Before the treatments, vines were tagged for identification and after that Shoot length was recorded during defoliation and after two weeks from the last defoliation treatment. The vines were cane pruned and trellised to bilateral vertical shoots. Canes were horizontally tied to three catch wires located at a distance of 90,120 and $150 \mathrm{~cm}$ above the ground. All regular management practices were carried out as recommended (Creasy and Creasy, 2018).

At harvest time, clusters were collected from the tagged shoots and analyzed. Data were recorded on Bunch Rot (\%), Bunch weight (g), no of lateral shoots, total soluble solids (\% TSS), titratable acidity (\% TA) total phenolics (\%), total sugars (\%) and reducing sugars (\%). Ten berries were randomly selected per replicate from each treatment and analyzed for different physico-chemical characteristics as described above. TSS was calculated using a hand held refractometer, while titratable acidity was determined using titration and expressed as percent malic acid. Using the Barratt-Horsfall scale, the percentage of infected clusters of bunch rot (BR) were rated for BR once per week on tagged shoots (Horsfall and Barratt, 1945). The ratings were converted to percentage of infected area employing Elanco conversion tables (Redman et al., 1969). The exterior surface area of vines was also rated to produce a single value estimate of total Bunch Rot. Total sugars and Reducing sugars of the juice were estimated by the method described by (Horwitz, 1960). Slinkard and Singleton (1977) defined the Folin-Ciocalteu method for calculating total phenol content $(\mathrm{mg} / \mathrm{g}$ of fresh weight) and expressing it as gallic acid equivalents (GAE).

Table 1: Climate characteristics of the experimental area during years 2017-18.

\begin{tabular}{|c|c|c|c|c|c|c|c|c|c|c|c|c|}
\hline \multirow[t]{2}{*}{ Climate characteristics } & \multicolumn{2}{|c|}{ April } & \multicolumn{2}{|c|}{ May } & \multicolumn{2}{|c|}{ June } & \multicolumn{2}{|c|}{ July } & \multicolumn{2}{|c|}{ August } & \multicolumn{2}{|c|}{ September } \\
\hline & 2017 & 2018 & 2017 & 2018 & 2017 & 2018 & 2017 & 2018 & 2017 & 2018 & 2017 & 2018 \\
\hline Average Max temperature $(\mathrm{C})$ & 32.9 & 29.6 & 35.5 & 32.9 & 34.5 & 36.5 & 32.5 & 31.8 & 32.5 & 31.4 & 28.8 & 20.6 \\
\hline Maximum temperature $\left({ }^{\circ} \mathrm{C}\right)$ & 40.1 & 35.5 & 41.4 & 39.3 & 46.2 & 39.4 & 37.4 & 36.5 & 36.3 & 36.5 & 33.5 & 36.1 \\
\hline Minimum temperature $\left({ }^{\circ} \mathrm{C}\right)$ & 11.2 & 10.4 & 11.9 & 17.5 & 19.8 & 21.3 & 18.8 & 22.7 & 20.6 & 18.4 & 17.2 & 14.5 \\
\hline Monthly rain (mm) & 36 & 73 & 112 & 14 & 50 & 110 & 212 & 102 & 121 & 99 & 60 & 30 \\
\hline Rainy days & 3 & 6 & 10 & 3 & 8 & 4 & 15 & 7 & 10 & 5 & 6 & 3 \\
\hline
\end{tabular}

September 2021 | Volume 37 | Issue 3 | Page 775 
Statistical analysis

During the experiment, a Randomized Complete Block Design (RCBD) was used, and the findings were analyzed using analysis of variance (ANOVA) and the least significant difference (LSD) test at a significance level of $\mathrm{p}<0.05$ by using Statistix 8.1 software package.

\section{Results and Discussion}

\section{Bunch weight}

Data on bunch weight indicated significant difference between control and defoliation at full bloom during the first year but it was calculated totally otherwise during the second year of research trail. Individual berry weight data was not counted in the both years of study. Tardáguila et al. (2010) reported that early leaf removal during the flowering season decreased yield by reducing bunch weight, berry size, and bunch compactness, while Mijowska et al. (2016) reported that defoliation treatments had no effect on berry and cluster weights. The observed significant difference can be attributed to seasonal impacts during the two years as inferred by Intrigliolo et al. (2014).

\section{Lateral shoots}

The number of lateral shoots was not significantly affected by the any leaf removal treatments during the first year of study but data showed that there was significant difference between control vines and vines where leaves were removed 4 weeks after bloom (Table 2). Lateral shoot values ranged from 6.45 to 7.25 in vines with leaf removal treatments whereas lateral shoot value in non-treated (control) ranged between 7.67 to 7.72. Leaf removal treatments are known to have a negative effect on vine growth due to decrease in photosynthesis activity as reported by (Petrie et al., 2003; Beslic et al., 2013; Luigi et al., 2020).

Total soluble solids (TSS)
TSS content increased in treatments with defoliation compared to control which had $18.80 \%$ and 18.32 $\%$ TSS respectively during the two years of the study. Defoliation at bloom and post-bloom phases had higher TSS values (19.25 and 19.61 percent, respectively), but they were statistically equivalent (Table 2). According to Mijowska et al. (2016), especially early defoliation, increases the amount of TSS in grapes. Similar findings were published by Nicolosi et al. (2012) and Vilanova et al. (2012), who reported that early leaf clipping can lead to increases accumulation of soluble solids.

\section{Titratable acidity (TA)}

When compared to non-leaf removal treatments, leaf removal showed a substantial decrease in titratable acidity during both years of research (Table 3 ). In control, TA was recorded at $0.42 \%$ during both years which was significantly higher than the other treatments $(0.38 \%-0.40 \%)$. In different studies, contradictory results have been reported regarding the impact of leaf removal on titratable acidity. Defoliated vines achieve higher sugar content and lower acidity, according to Baiano et al. (2015) and Mijowska et al. (2016), while Hed and Centinari (2018) found no significant differences in fruit composition in terms of TSS, $\mathrm{pH}$, and TA.

\section{Total phenolics}

Grapes had a total phenolic content ranging from 0.57 to $0.76 \mathrm{mg} / \mathrm{g}$ FW (Table 3). Phenolic content was slightly higher in the leaf removal treatments than controls, which had lower total phenolic content (0.57 and 0.64 percent, respectively) during both years. During the second year phenolic content was comparatively lower in the late bloom treatment. Excessive exposure of grapes to sunlight is known to enhance the biosynthesis of flavonoids (Mato et al., 2017). According to Beslic et al. (2013),

Table 2: Impact of defoliation treatments on bunch weight, lateral shoots and total soluble solids of King's Ruby grapes.

\begin{tabular}{llllccc} 
Leaf removal stage & \multicolumn{2}{c}{ Bunch weight (g) } & \multicolumn{2}{c}{ Lateral shoots } & \multicolumn{2}{c}{ TSS (\%) } \\
& 2017 & 2018 & 2017 & 2018 & 2017 & 2018 \\
No defoliation & $404.75 \pm 12.7$ & $401.64 \pm 7.8$ & $7.67 \pm 0.52$ & $7.72 \pm 0.43$ & $18.80 \pm 0.29$ & $18.32 \pm 0.50$ \\
Before bloom & $439.95 \pm 25.5$ & $423.14 \pm 6.8$ & $7.10 \pm 0.12$ & $7.25 \pm 0.50$ & $19.25 \pm 0.25$ & $19.25 \pm 0.27$ \\
At Bloom & $459.20 \pm 18.3$ & $425.30 \pm 7.2$ & $6.60 \pm 0.61$ & $6.97 \pm 0.23$ & $19.61 \pm 0.17$ & $19.50 \pm 0.11$ \\
Four weeks after bloom & $426.98 \pm 11.8$ & $410.48 \pm 5.0$ & $6.45 \pm 0.22$ & $6.70 \pm 0.21$ & $19.46 \pm 0.30$ & $19.42 \pm 0.10$ \\
LSD & 16.41 & 6.36 & 0.38 & 0.29 & 0.22 & 0.23
\end{tabular}

LSD: Least Significant difference. Means within columns followed by different letters differ significantly $(P \leq 0.05)$. 
early defoliation during intense shoot growth reduced the overall photosynthesis because of a smaller leaf area, resulting in more limited sink organ growth and, finally, an increase in phenolic content accumulation in grapes. Early leaf removal increased soluble solids, total polyphenols, and anthocyanins, according to Nicolosi et al. (2012) and Vilanova et al. (2012).

Table 3: Impact of defoliation treatments on titratable acidity and total phenolics of King's Ruby grapes.

\begin{tabular}{lllll}
$\begin{array}{l}\text { Leaf removal } \\
\text { stage }\end{array}$ & \multicolumn{2}{c}{ TA (\%) } & \multicolumn{2}{c}{$\begin{array}{c}\text { Total phenolics }(\mathrm{mg} / \mathrm{g} \\
\text { FW) }\end{array}$} \\
\cline { 2 - 5 } & 2017 & 2018 & 2017 & 2018 \\
No defoliation & $0.42 \pm 0.01$ & $0.42 \pm 0.02$ & $0.57 \pm 0.02$ & $0.64 \pm 0.01$ \\
Before bloom & $0.38 \pm 0.01$ & $0.39 \pm 0.02$ & $0.74 \pm 0.02$ & $0.74 \pm 0.02$ \\
At Bloom & $0.39 \pm 0.01$ & $0.39 \pm 0.02$ & $0.74 \pm 0.01$ & $0.76 \pm 0.01$ \\
$\begin{array}{l}\text { Four weeks } \\
\text { after bloom }\end{array}$ & $0.38 \pm 0.01$ & $0.40 \pm 0.02$ & $0.72 \pm 0.01$ & $0.70 \pm 0.01$ \\
LSD & 0.14 & 0.01 & 0.01 & 0.01
\end{tabular}

LSD: Least Significant difference. Means within columns followed by different letters differ significantly $(P \leq 0.05)$.

\section{Total sugars (TS)}

Total sugars contents increased dramatically in leaf removal treatments during both years of the study as compared to non-leaf removal treatments, which had 13.75 percent and 14.02 percent, respectively, as shown in (Figure 1). According to Porikha et al. (2015) the higher total sugars contents in the leaf removal treatments may be due to passive metabolite rivalry, a small number of bunches per plant, and the availability of more photosynthates, which eventually contributes to greater vigour and physiological activity and a balance source-sink relationship.

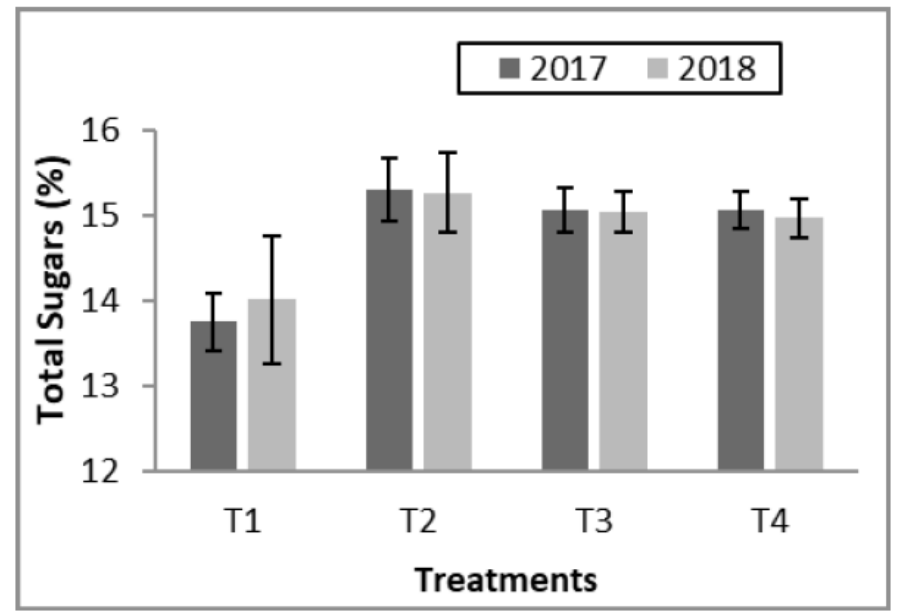

Figure 1: Effect of fruit zone leaf removal on total sugars; $T 1=$ Non defoliated control; T2=Defoliation at pre-bloom stage; T3=Defoliation at bloom stage and T4=Defoliation at 4 weeks after bloom.
Reducing sugars ( $R S$ )

The reducing sugars also increased in all leaf removal treatments (Figure 2). During both years of the study, the control treatments had lower percentages of reducing sugars (13.46 percent and 13.28 percent), which was slightly lower than the other treatments. Leaf thinning, according to Patel et al. (2014) and Song et al. (2018), accumulates carbohydrates to ignite growth and development, rising fruit weight and accelerating ripening. These factors eventually contribute to increased berry ripening and improved quality, resulting in higher sugar and soluble solid content.

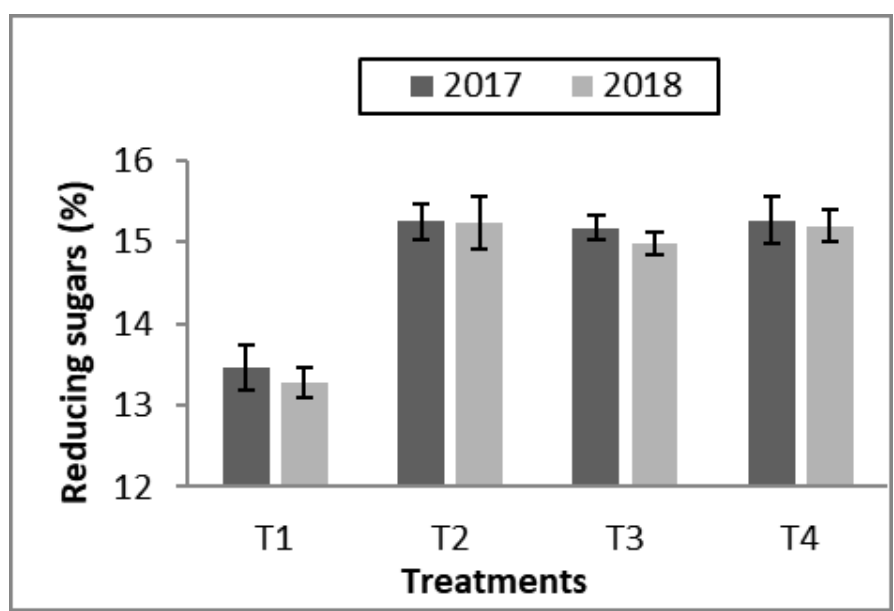

Figure 2: Effect of fruit zone leaf removal on reducing sugars; T1=Non defoliated control; T2=Defoliation at pre-bloom stage; $T 3=$ Defoliation at bloom stage and T4= Defoliation at 4 weeks after bloom.

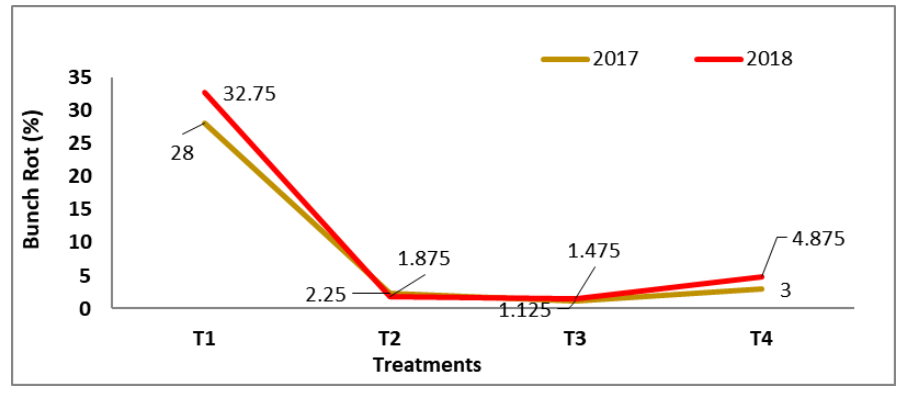

Figure 3: Effect of fruit zone leaf removal on bunch rot of grapes; T1=Non defoliated control; T2=Defoliation at pre-bloom stage; $T 3=$ Defoliation at bloom stage and T4= Defoliation at 4 weeks after bloom.

\section{Bunch rot}

Bunch rot incidence was significantly less in the leaf removal treatments relative to control during the two years (Figure 3). Control (non removal) had significantly higher percentage (28\% and $32.75 \%)$ of bunch rot, while its incidence was less than $5 \%$ in all leaf removal treatments. Pre-bloom fruit-zone leaf removal has been shown to minimize bunch rot susceptibility (Hed and Centinari, 2018). According 
to Risco et al. (2014), during early fruit-zone leaf removal, a larger portion of leaf area is removed pershoot, resulting in reduced cluster compactness and improved canopy microclimate and spray coverage (Diago et al., 2010; Sabbatini and Howell, 2010), which lowers disease incidence as a positive trend.

\section{Conclusions and Recommendations}

The proper penetration of light and air in the plants, as a result of leaf removal, decreases occurrence and severity of bunch rot disease. Fruit Zone Leaf Removal (FZLR) was found to be a useful phenomenon with a significant effect on vegetative and other quality parameters in grape cv. King's Ruby. Defoliation increased total soluble solids, total phenolic content, total sugars, and reducing sugars while decreasing titratable acidity and severity of bunch rot.Defoliation, on the other hand, had no effect on bunch weight (cluster of grapes). This technique is extremely useful for preserving grape quality and quantity without the use of chemicals to fight disease. As a result, this policy is both environmentally sustainable and beneficial to human health. We suggest using leaf removal therapy to treat bunch rot disease in grapes in Pakistan because it is the least expensive treatment.

\section{Novelty Statement}

Leaf removal is a cheap and bio friendly alternative for control of bunch rot in grapes without the use of harmful fungicides. It is an economical alternative for the farmers to get disease free fruit.

\section{Author's Contribution}

Allah Bakhsh: Helped in devising, layout, supervising the experiment and proofreading.

Attiq Akhtar: Write up of the manuscript and data analysis.

Fiaz Hussain and Shabbir Ahmed: Collection and tabulation of experiment data.

\section{Conflict of interest}

The authors have declared no conflict of interest.

\section{References}

Austin, C.G., G.G. Grove, J.M. Meyers and W.F. Wilcox. 2011. Powdery mildew severity as a function of canopy density: Associated impacts on sunlight penetration and spray coverage. Am. J. Enol. Viticult., 62: 23-31. https://doi. org/10.5344/ajev.2010.10077

Baiano, A., A. De Gianni, M.A. Previtali, M.A. del Nobile, V. Novello and L. de Palma. 2015. Effects of defoliation on quality attributes of Nero di Troia (Vitis vinifera L.) grape and wine. Food Res. Int., 75: 260-269. https://doi. org/10.1016/j.foodres.2015.06.007

Beslic, Z., S. Todic and S. Matijasevic. 2013. Effect of timing of basal leaf removal on yield components and grape quality of grapevine cvs Cabernet Sauvignon and Prokupac (Vitis vinifera L.). Bulg. J. Agric. Sci., 19: 96-102.

Coombe, B.G., 1987. Influence of temperature on composition and quality of grapes. Acta Hortic., 206: 23-35. https://doi.org/10.17660/ ActaHortic.1987.206.1

Creasy, M. and L. Creasy. 2018. Grapes. $2^{\text {nd }}$ Edn. CABI, UK. https://doi. org/10.1079/9781786391360.0000

Diago, M.P., M. Vilanova and J. Tardaguila. 2010. Effects of timing of manual and mechanical early defoliation on the aroma of Vitis vinifera L. Tempranillo wine. Am. J. Enol. Viticult., 61: 382-391.

English, J.T., C.S. Thomas, J.J. Marois and W.D. Gubler. 1989. Microclimates of grapevine canopies associated with leaf removal and control of botrytis bunch rot. Phytopathology, 79: 395-401. https://doi.org/10.1094/ Phyto-79-395

Gerasopoulos, D. and P.D. Drogoudi. 2005. Summer-pruning and preharvest calcium chloride sprays affect storability and low temperature breakdown incidence in kiwi fruit. Postharvest Biol.Technol., 36: 303-308.https:// doi.org/10.1016/j.postharvbio.2005.01.005

Hed, B. and M. Centinaro. 2018. Hand and mechanical fruit-zone leaf removal at prebloom and fruit-set was more effective in reducing crop yield than reducing bunch rot in 'riesling' grapevines. Hortic. Technol., 28(3): 296-303. https://doi.org/10.21273/ HORTTECH03965-18

Horsfall,J.G. and R.W. Barratt. 1945. An improved grading system for measuring plant disease. Phytopathology, 35: 655.

Horwitz, W., 1960. Official and tentative methods of analysis. 9 $^{\text {th }}$ edition, Association of Official Agricultural Chemists, Washington D.C. pp. 


\section{4-320.}

Intrigliolo, D.S., E. Llacer, J. Revert, M.D. Esteve, D., Climent, D. Palau and I. Gómez. 2014. Early defoliation reduces cluster compactness and improves grape composition in Mandó, an autochthonous cultivar of Vitisvinifera from southeastern Spain. Scient. Hortic., 167: 71-75. https://doi.org/10.1016/j.scienta.2013.12.036

Jackson,D.I. and P.B.Lombard.1993.Environment and management practices affecting grape composition and wine quality. A review. Am. J. Enol. Viti., 4: 409-430.

Kashif, R., F.U.Haq,J.Amin, A. Shah and U. Khan. 2018. Grapes Characterization of Different Varieties in the Central Zone of Peshawar KPK. Int. J. Environ. Sci. Nat. Res., 9(1): 555754.

Kemp, B., R. Harrison and G.L. Creasy. 2010. The effect of timing of mechanical leaf removal on Pinot noir berry and wine composition. Proc. $7^{\text {th }}$ Int. Cool Clim. Symp., Seattle, Washington, USA.

Komm, B.L. and M.M. Moyer. 2015. Effect of early fruit-zone leaf removal on canopy development and fruit quality in Riesling and Sauvignon blanc. Am. J. Enol. Viticult., 66: 424-434. https://doi.org/10.5344/ajev.2015.15007

Luigi, T., M. Faccia, G. Masi and G. Gambacorta. 2020. The impact of early basal leaf removal at different sides of the canopy on aglianico grape quality. Agriculture, 10(630): 1-13. https://doi. org/10.3390/agriculture10120630

Mato, D., V. Jukić, K. Zmaić, T. Kujundžić and V. Rastija. 2017. Effects of early leaf removal on grape yield, chemical characteristics, and antioxidant activity of grape variety Cabernet Sauvignon and wine from Eastern Croatia, Acta Agric. Scand. B Soil Plant Sci.,

Mijowska, K., I. Ochmian and J. Oszmianski. 2016. Impact of cluster zone leaf removal on grapes cv. Regent Polyphenol Content by the UPLCPDA/MS Method. Molecules, 21: 1688-1701. https://doi.org/10.3390/molecules21121688

Nicolosi, E., A. Continella, A. Gentiloe, A. Cicala and F. Ferlito. 2012. Influence of early leaf removal on utochthonous and international grapevines in Sicily. Sci. Hortic-Amsterdam, 146: $\quad 1-6 . \quad$ https://doi.org/10.1016/j. scienta.2012.07.033

Ozer, C., A.S. Yasasm, O. Ergonul and S. Aydin. 2012. The effects of berry thinning and gibberellins on receluzumu table grapes. Pak. J.
Agric. Sci., 49(2): 105-112.

Palliotti, A., F. Panara, O. Silvestroni, V. Lanari, P. Sabbatini, G.S. Howell, M. Gatti and S. Poni. 2013. Influence of mechanical postveraison leaf removal apical to the cluster zone on delay of fruit ripening in Sangiovese (Vitis vinifera L.) grapevines. Aust. J. Grape Wine Res. 19(3): 1-9. https://doi.org/10.1111/ajgw.12033

Patel, R.K., S.B. Meitei, A. Kumar, K. Srivastava, B.C. Deka, N.A. Deshmukh and V.K. Verma. 2014. Effect of leaf and fruit thinning on yield and quality of peach cv. FlordaSun. J. Environ. Sci., 6:467-471.

Petrie, P.R., M.C.T. Trought, G.S. Howell and G. Buchan. 2003. The effect of leaf removal and canopy height on whole-vine gas exchange and fruit development of Vitis vinifera L. Sauvignon blanc. Funct. Plant Biol., 30: 711-717. https:// doi.org/10.1071/FP02188

Porikha, H., M. Jagadeesha and M. Suchithra. 2015. Effect of pruning severity on quality of grapes $\mathrm{Cv}$. Red globe for summer season. Adv. Crop Sci. Tech., S1: 04. https://doi. org/10.4172/2329-8863.1000S1-004

Radwan, E.M.A. and A.A.B. Masood. 2017. Effect of Thinning practices on fruiting of ruby seedless grapevine assiut. J. Agric. Sci., 48(4): 145-153. https://doi.org/10.21608/ajas.2017.5016

Redman, G.E., E.P. King and I.F. Brown. 1969. Elanco conversion tables for Barratt-Horsfall rating numbers. Elanco Products Co., Indianapolis, IN.

Reynolds, A.G., D.A. Wardle and A.P. Naylor. 1996. Impact of training system, vine spacing, and basal leaf removal on Riesling. Vine performance, berry composition, canopy microclimate, and vineyard labor requirements. Am. J. Enol. Vit., 47: 63-76.

Risco, D., D. Perez, A. Yeves, J.R. Castel and D.S. Intrigliolo. 2014. Early defoliation in a temperate warm and semi-arid Tempranillo vineyard: Vine performance and grape composition. Aust. J. Grape Wine Res., 20: 111-122. https:// doi.org/10.1111/ajgw.12049

Sabbatini, P. and G.S. Howell. 2010. Effects of early defoliation on yield, fruit composition, and harvest season cluster rot complex of grapevines. Hortic. Sci., 45: 1804-1808. https:// doi.org/10.21273/HORTSCI.45.12.1804

Slinkard, K. and V.L. Singleton. 1977. Total phenol analysis: Automation and comparison with 
manual methods. Am. J. Enol. Vitic., 28: 49-55.

Song, C.Z., C. Wang, S.Xie and Z.W.Zhang. 2018.

Effects of leaf removal and cluster thinning on berry quality of Vitis vinifera cultivars in the region of Weibei Dryland in China. J. Integ. Agric., 17(7): 1620-1630. https://doi. org/10.1016/S2095-3119(18)61990-2

Tardáguila, J., M.D. Toda, S. Ponie and M.P. Diago. 2010. Early leaf removal impact on yield components, fruit, and wine composition of Graciano and Carignan (Vitisvinifera L.) grapevines. Am. J. Enol. Vitic., 61: 372-381.

Toaldo, I.M., V. Camp, J. Gonzales, G.B. Kamiloglu, S. Bordignon-Luiz, M.T. Smagghe, G. Raes, E. Capanoglu, C. Grootaert and C. Resveratrol. 2016. TNF improves induced endothelial dysfunction in a coculture model of a Caco-2 with an endothelial cell line. J. Nutr. Biochem., 36: 21-30. https://doi.org/10.1016/j. jnutbio.2016.07.007

Vicente, A. and J.Juste. 2015. Cluster thinning in cv. Verdejo rained grown: physiologic, agronomic and qualitative effects in the D.O. Rueda (Spain). Biol. Web. Conf., 5: 01020. https://doi. org/10.1051/bioconf/20150501020

Vilanova, M., M.P. Diago, Z. Genisheva, J.M. Oliveira and J. Tardaguila. 2012. Early leaf removal impact on volatile composition of Tempranillo wines. J. Sci. Food Agric., 92: 935942. https://doi.org/10.1002/jsfa.4673

Xia, E.Q., G.F. Deng, Y.J. Guo and H.B. Li. 2010. Biological activities of polyphenols from grapes. Int. J. Mol. Sci., 11: 622-646. https:// doi.org/10.3390/ijms11020622

Zhou, K. and J.J. Raffoul. 2012. Potential anticancer properties of grape antioxidants. J. Oncol., 2012: 1-8. https://doi.org/10.1155/2012/803294 